\begin{tabular}{|c|c|c|c|c|c|}
\hline \multicolumn{6}{|c|}{ DISTRIBUTION SHEET } \\
\hline To & \multirow{2}{*}{\multicolumn{3}{|c|}{$\begin{array}{l}\text { From } \\
\text { BRAD CARPENTER }\end{array}$}} & \multicolumn{2}{|c|}{ Page 1 of 1} \\
\hline DISTRIBUTION & & & & \multicolumn{2}{|c|}{ Date $12-14-94$} \\
\hline \multirow{2}{*}{\multicolumn{4}{|c|}{$\begin{array}{l}\text { Project Title/Work Order } \\
\text { TANK 241-BX-104 TANK CHARACTERIZATION PLAN }\end{array}$}} & \multicolumn{2}{|c|}{ EDT No. 610004} \\
\hline & & & & \multicolumn{2}{|c|}{ ECN No. } \\
\hline Name & MSIN & $\begin{array}{c}\text { Text } \\
\text { With All } \\
\text { Attach. }\end{array}$ & Text Only & $\begin{array}{l}\text { Attach./ } \\
\text { Appendix } \\
\text { Only }\end{array}$ & $\begin{array}{l}\text { EDT/ECN } \\
\text { Only }\end{array}$ \\
\hline $\begin{array}{l}\text { BC CARPENTER } \\
\text { CS HALLER } \\
\text { KK KELLLER } \\
\text { JW OSBORNE } \\
\text { DL EDWARDS } \\
\text { SC GOHEEN } \\
\text { RA JENKINS/B CARPENTER }\end{array}$ & $\begin{array}{l}\text { R2-12 } \\
\text { R2-12 } \\
\text { S1-57 } \\
\text { S7-15 } \\
\text { S3-90 } \\
\text { P8-08 } \\
\text { R2-12 }\end{array}$ & $\begin{array}{l}x \\
X \\
X \\
X \\
X \\
X \\
X \\
X \\
X \\
\\
\\
\text { DI }\end{array}$ & $\begin{array}{l}\text { ISIN PROVI } \\
\text { RIBUTION. }\end{array}$ & D SENT TO & AUTHOR FOR \\
\hline $\begin{array}{l}\text { OSTI } \\
\text { CENTRAL FILES }\end{array}$ & $\begin{array}{l}\text { L8-07 } \\
\text { L8-04 }\end{array}$ & $2 \mathrm{PL}$ & ORIGINAL & & \\
\hline
\end{tabular}




\section{DISCLAIMER}

Portions of this document may be illegible in electronic image products. Images are produced from the best available original document. 


\begin{tabular}{l|l|}
\hline ?. To: (Receiving Organization) & 3. From: coriginating Organization) \\
FIELD ANALYTICAL SERVICES & THRS/CHARACTERIZATION SUPPORT \\
\hline 5. Proj./Prog./Dept./Div.: & 6. Cog. Engr.: \\
TWRS ENG/CHAR SUPPORT & B. C. CARPENTER \\
\hline
\end{tabular}

8. Originator Remarks:

N/A
4. Related EDT HO.:

$N / A$

7. Purchase Order Ho.:

$N / A$

9. Equip./Component No.:

$N / A$

10. System/Bldg./Facility:

$2750 E / 200 E$

12. Hajor Assm. Dwg. No.:

N/A

13. Permit/Permit Application Ho.: $N / A$

14. Required Response Date:

$12 / 14 / 94$

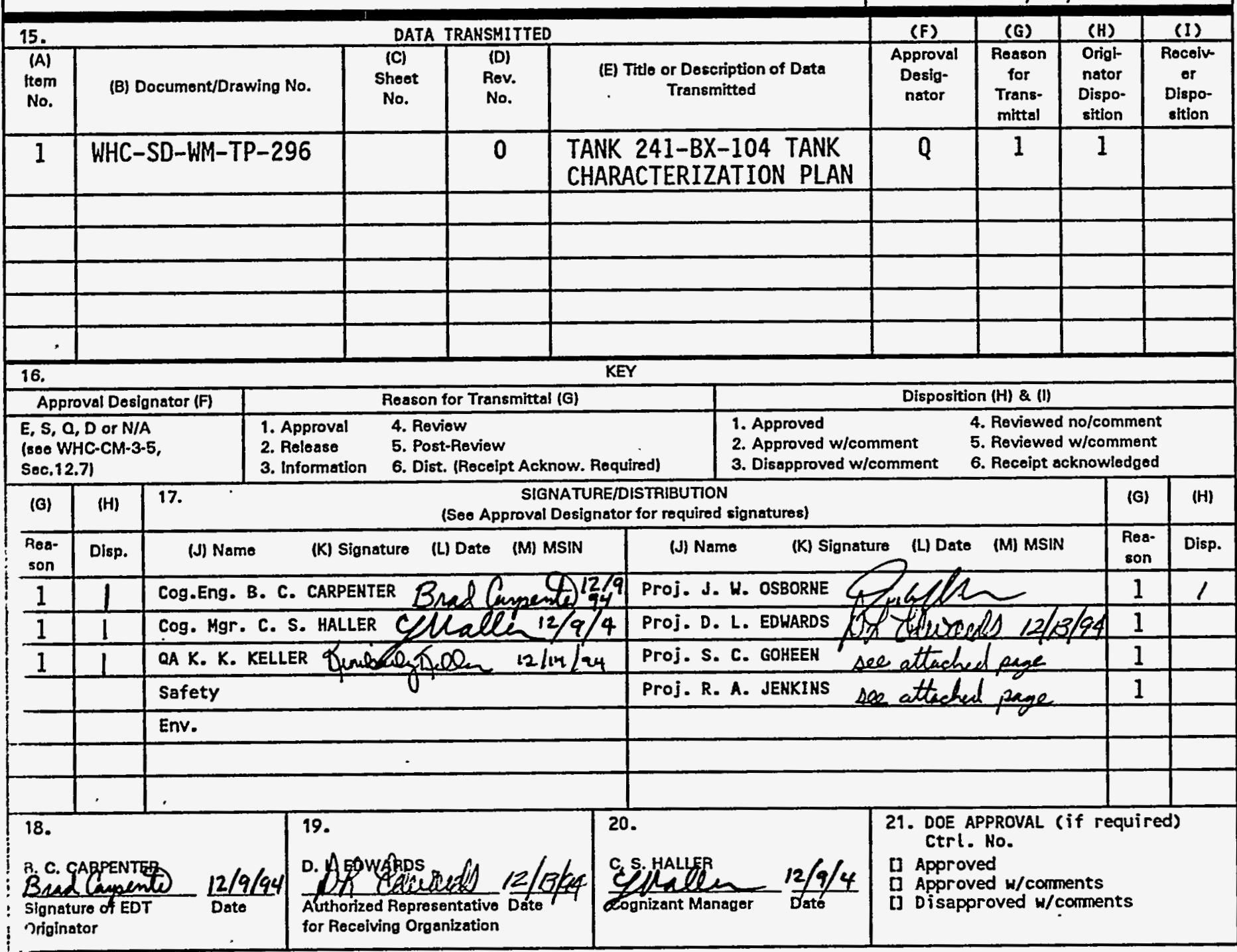

:-7400-172-2 (04/94) GEF097 


\begin{tabular}{|c|c|}
\hline $\begin{array}{l}\therefore \text { To: (REeEIVIns Orgenizetion) } \\
\text { FIELO ANALYTICAL SERVICES }\end{array}$ & $\begin{array}{l}\text { 5. from: rariginsting ergenizations } \\
\text { THRS/CHARACTERIZRTION SUPPORT }\end{array}$ \\
\hline $\begin{array}{l}\text { 5. Proj./Prog./Popt./0iv.: } \\
\text { TWRS ENG/CHAR SUPPORT }\end{array}$ & $\begin{array}{l}\text { 6. cog. EnPr.: } \\
\text { Q. C. CARPENTER }\end{array}$ \\
\hline
\end{tabular}

\section{Orfalnator Rcourks:}

N/A

\section{Relered EDT Ho.: \\ $N / A$ \\ 7. Purehase Order Mo.z N/A}

9. Equlp./Component Mo.1 $N / A$

10. systensteds.ffocllity: $2750 E / 200 E$

12. Kejor kesm. Dug. Ko.: $\mathrm{H} / \mathrm{A}$

is. Permisffermit hasileztion ke.: $N / A$

16. Required Reeponse Dato: $12 / 14 / 94$

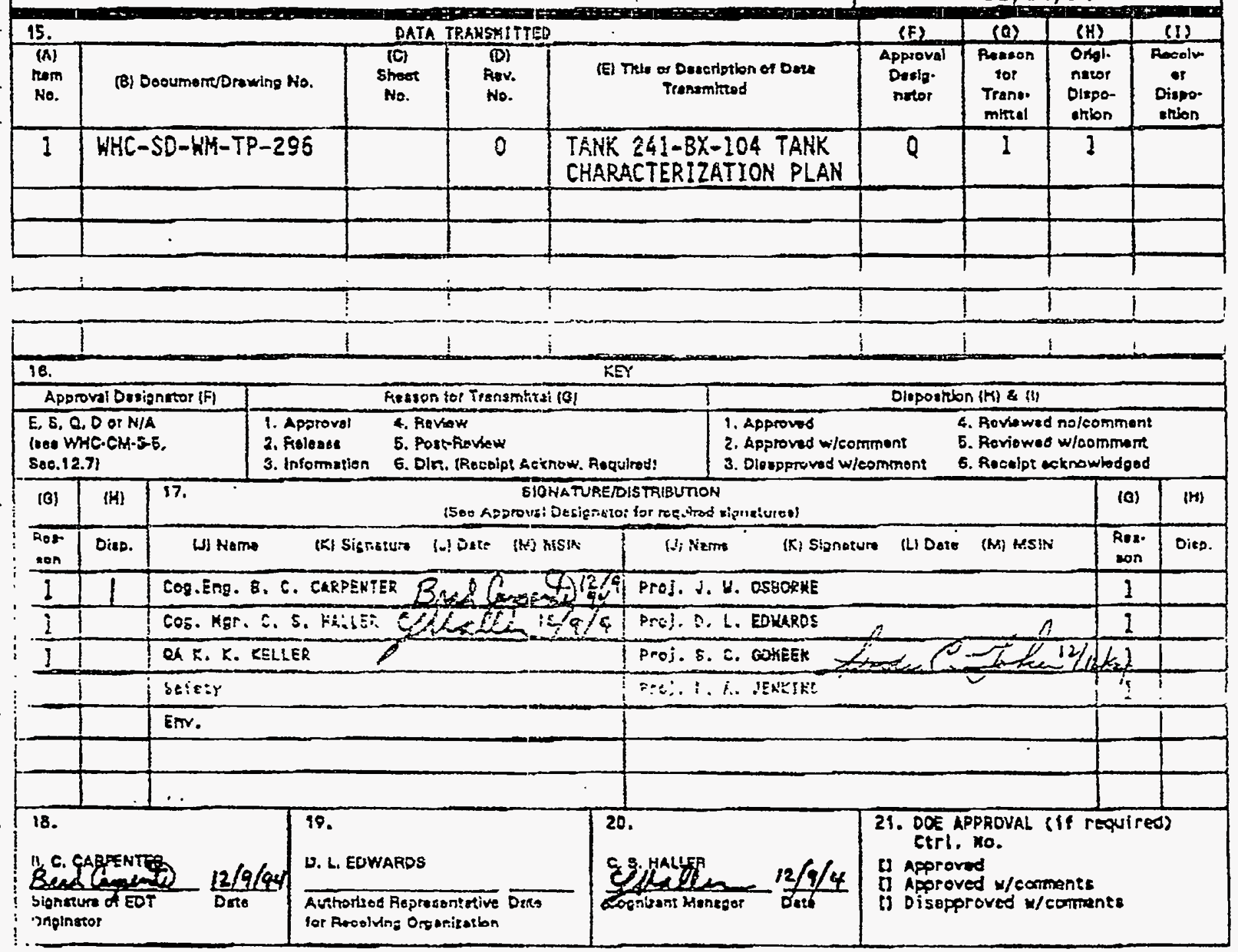




\section{ENGINEERINE DATA TRANEMITTAL}

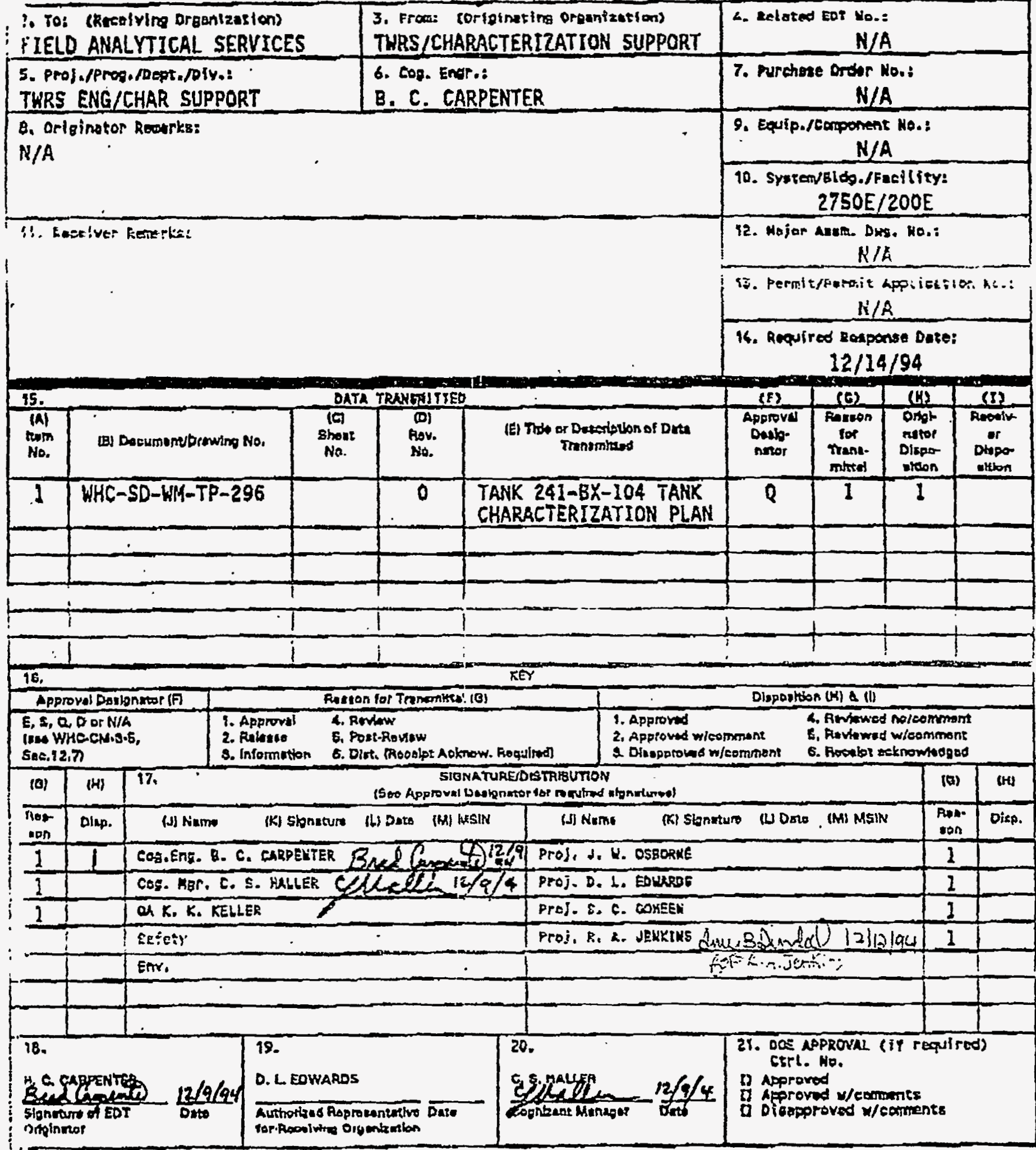

$\because-7400-176-2(04 / 9 h)$ GEF097 
2. Title

3. Number WHC-SD-WM-TP-296

6. Author

5. Key Hords

CHARACTERIZATION, DQO, HEALTH AND SAFETY VAPOR

ISSUE, FERROCYANIDE, QUALITY CONTROL, SINGLE-SHELL TANK, VAPOR SAMPLING, ANALYSIS, TANK CHARACTERIZATION PLAN

APPROVED FOF

Hame: B. C. CARPENTER

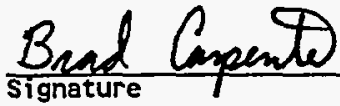

7. Abstract

This document is a plan which serves as the contractual agreement between the Characterization Program, Sampling Operations, Oak Ridge National Laboratory, and PNL tank vapor program. The scope of this plan is to provide guidance for the sampling and analysis of vapor samples from tank 241-BX-104.

8.

RELEASE STAMP

OFFICIAL RELEASE BY WHC

DATE DEC 141994 stow, 4 0 
WHC-SD-WM-TP-296

Revision 0

\title{
Tank 241-BX-104 Tank Characterization Plan
}

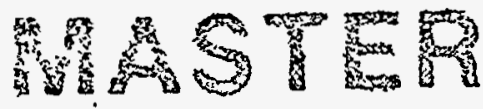 \\ Prepared for the U.S. Department of Energy. \\ Office of Environmental Restoration \\ and Waste Management
}

\section{DISCLAIMER}

This report was prepared as an account of work sponsored by an agency of the United States Government. Neither the United States Government nor any agency thereof, nor any of their employees, makes any warranty, express or implied, or assumes any legal liability or responsibility for the accuracy, completeness, or usefulness of any information, apparatus, product, or process disclosed, or represents that its use would not infringe privately owned rights. Reference herein to any specific commercial product, process, or service by trade name, trademark, manufacturer, or otherwise does not necessarily constitute or imply its endorsement, recommendation, or favoring by the United States Government or any agency thereof. The views and opinions of authors expressed herein do not necessarily state or reflect those of the United States Government or any agency thereof. 


\section{TABLE OF CONTENTS}

1.0 SPECIFIC TANK CHARACTERIZATION OBJECTIVES .......... 1

1.1 Data Quality Objectives Applicable to Tank BX-104 ....... I

2.0 RELEVANT SAFETY INFORMATION ................. 1

2.1 Tank Status ..................... 2

2.2 Tank Monitoring Activities ............. 2

3.0 SUMMARY OF HISTORICAL INFORMATION FOR TANK BX-104 . . . . . . 2

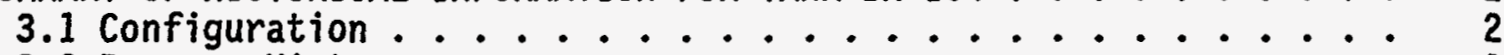

3.2 Process History ................. 2

3.3 Historical Sampling Events ............... 4

3.4 Expected Tank Contents ............... 6

4.0 REFERENCES ............................ 8

APPENDICES: TANK 241-BX-104 SAMPLING AND ANALYSIS PLAN . . . . . . A

SAMPLE EVENT A: VAPOR SAMPLING IN FISCAL YEAR $1995 \ldots \ldots \ldots$

\section{LIST OF TABLES}

Table 1. Tank BX-104 Core Composite Analyses Results. . . . . . . . . 4

Table 2. Tank BX-104 Vapor Sample Analyses Results. . . . . . . . . 7

\section{LIST OF FIGURES}

Figure 1. Fill history of Tank 241-BX-104. .......... 3

\section{LIST OF ACRONYMS}

$\begin{array}{ll}\text { BX-104 } & \text { Tank 241-BX-104 } \\ \text { DQO } & \text { data quality objective } \\ \text { DST } & \text { double-shel1 tank } \\ \text { FIC } & \text { Food Instrument Corporation } \\ \text { GC/FID } & \text { Gas chromatograph/flame ionization detector } \\ \text { GC/MS } & \text { Gas chromatograph/mass spectometry } \\ \text { NIOSH } & \text { NationaT Institute of Occupational Safety and Health } \\ \text { PpmV } & \text { parts per million by volume } \\ \text { PUREX } & \text { Plutonium-Uranium Extraction plant } \\ \text { RCRA } & \text { Resource Conservation and Recovery Act } \\ \text { SST } & \text { single-shell tank } \\ \text { TOC } & \text { total organic carbon } \\ \text { TO-12 } & \text { EPA task order protocol 12 } \\ \text { TO-14 } & \text { EPA task order protocol 14 } \\ \text { THRS } & \text { WHC Tank Waste Remediation System } \\ \text { WHC } & \text { Westinghouse Hanford Company }\end{array}$




\section{TANK 241-BX-104 TANK CHARACTERIZATION PLAN}

\subsection{SPECIFIC TANK CHARACTERIZATION OBJECTIVES}

This Tank Characterization Plan will identify characterization objectives for tank BX-104 pertaining to sample collection, sample preparation and analysis, and laboratory analytical evaluation and reporting requirements in accordance with the Tank Waste Remediation System Tank Waste Analysis Plan (Ha7ler 1994) and the applicable Data Quality Objectives identified in the following section. In addition, the current status (Section 2) and contents estimate (Section 3 ) of the tank is given.

\subsection{Data Quality Objectives Applicable to Tank BX-104}

The sampling and analytical needs associated with the 51 Hanford Site underground storage tanks classified on one or more of the four Watch Lists (ferrocyanide, organic, flammable gas, and high heat), and the safety screening of all 177 tanks have been identified through the Data Quality Objective (DQO) process. DQO's identify information needed by a program group in the Tank Haste Remediation System (TWRS) concerned with safety issues, regulatory requirements, or the transporting and processing of tank waste.

The Tank Safety Screening Data Quality Objective (Redus and Babad 1994) describes the sampling and analytical requirements that are used to screen waste tanks for unidentified safety issues. To meet the sampling requirements of this DQO effort, a vertical profile of the waste shall be obtained from at least two widely-spaced risers. This vertical profile may be realized using core, auger, or grab samples. The safety screening analyses shall be applied to al1 core samples, DST RCRA samples, and all auger samples, except auger samples taken exclusively to assess the flammable gas tank crust burn issue.

Both Watch List and non-Watch List tanks will be sampled and evaluated to classify the waste tanks into one of three categories: SAFE, CONDITIONALLY SAFE, or UNSAFE following safety parameters related to the four Watch-List and other safety issues. Since tank BX-104 is identified as a non-Watch List tank, only the safety screening DQO applies to current sampling and analytical requirements.

DQO's concerned with fugitive vapor emissions from tank $\mathrm{BX}-104$ are: Data Quality Objectives for Generic In-Tank Health and Safety Vapor Issue Resolution (Osborne et a7. 1994); and Rotary Sampling Core Vapor Sampling Data Quality Objective (Price 1994). Characterization of the tank headspace is needed to: 1) identify those tanks which can safely be sampled with intrusive equipment without risk of gas ignition; 2) identify and estimate concentrations of toxicologically significant compounds present in the tank headspace to establish worker safety precautions; and 3) support the startup and operation of the portable exhauster used during rotary mode core sampling.

\subsection{RELEVANT SAFETY INFORMATION}

Resolution of tank vapor safety issues involve the identification of potential flammable and fugitive vapor emissions from tanks which could become worker health and safety hazards. 


\subsection{Tank Status}

Single-shell tank BX-104 is classified as an non-Watch List tank. The tank is sound, and was interim stabilized in 1989. To prevent further waste addition, intrusion prevention was completed. The tank is out of compliance with regard to waste temperature monitoring since internal tank temperature cannot be measured with present equipment. The last temperature measurement of $31^{\circ} \mathrm{C}$ was recorded in October, 1980 (Hanton 1994). Recent waste Tevel measurements have maintained a consistent level of 80.3 to $81.3 \mathrm{~cm}$ (Brevick et a?. 1994).

This tank is estimated to contain $375,000 \mathrm{~L}(99,000$ gallons) of non-complexed waste. The waste is comprised of $364,000 \mathrm{~L}$ (96,000 gallons) of sludge containing $113,000 \mathrm{~L}(30,000$ gallons $)$ of drainable interstitial liquid. The remaining $11,000 \mathrm{~L}(3,000$ gallons) is supernatant liquid (Hanlon 1994).

\subsection{Tank Monitoring Activities}

Waste level measurements are taken on a daily basis through riser 8 using an automatic FIC gauge. Internal tank temperature is not available. Six active dry wells monitor radiation in the surrounding soil (Hanton 1994).

\subsection{SUMMARY OF HISTORICAL INFORMATION FOR TANK BX-104}

Included in this section are a -physical description of tank BX-104, its process history, and recorded sampling events.

\subsection{Configuration}

Tank BX-104 is one of 12 single-shell tanks in the 200 East area BX Farm constructed during 1946-47. It is 23 meters (75 ft.) in diameter with a concave base and has a 2.01 million liter $(530,000$ ga7.) tank capacity. The tank was constructed as the primary tank in a cascade containing tanks BX-105 and $B X-106$; tank BX-106 may also cascade to primary cascade tank BY-103 (Brevick et al. 1994).

\subsection{Process History}

Tank BX-104, beginning service in the first quarter of 19.49 as a primary cascade receiver, was a filled to capacity with metal waste. After sluicing the metal waste to recover uranium in 1954, the tank may have been filled with waste from both the U Plant uranium recovery process and from ferrocyanide scavenged waste receivers $B Y-106$ and $B Y-110$. After a short period of settling, the supernatant was pumped to the $B C-13$ ditch in 1957 . The tank received PUREX cladding waste in 1962-65, likely from tanks $C-102$ and $C-108$ and cesium recovery waste from B Plant in 1967-76. It also may have received saltcake waste from BY Farm in-tank solidification units. During the period 1976-80 tank BX-104 was identified as containing both evaporator feed and double-shell slurry feed waste from the 242-A evaporator. A liquid level adjustment occurred in 1980, after which the tank was deactivated. Additional liquid level adjustments occurred in 1982 and 1989. Figure 1 summarizes the fill history of tank BX-104 from 1945 to the present (Brevick et al. 1994). 




$m$ 


\subsection{Historical Sampling Events}

Several supernatant samples were taken during 1974-5 in preparation for the startup of the 242-S Evaporator (Brevick et a1. 1994). These were dilute aqueous solutions of mainly sodium nitrate, sodium nitrite, and sodium carbonate. Two cores, consisting of three segments (Core $1,86 \mathrm{~cm}$ in 7 ength) and two segments (Core 2, $81 \mathrm{~cm}$ in length), were retrieved in February 1986 from risers 1 and 8 , respectively when the tank contained a $102 \mathrm{~cm}$ level of waste with a liquid surface.

Observations made during extrusion and phase separation indicate that the top layer was primarily aqueous liquid with a smal1 amount of solids and organic material. The middle portion contained much more solid material $(>50 \%)$ and a significant fraction of organic liquid (up to $14 \%$ ). The bottom layer was a thick sludge containing less than $10 \%$ drainable 1iquid. From each core a solids composite sample was made. In addition, a drainable liquid composite was blended from the aqueous phase of the Core 2 segments. No results, except the volumes recovered, were reported for the organic phase. The solid composites were prepared by a sequential 1iquid dissolution using a water leach, an acid leach, and finally a fusion dissolution. The acid leach solution was proportionally combined with the fusion dissolution sample solution prior to analysis. The analytical results for the three composites is given in Table 1 (Weiss and Schull 1988).

Table 1. Tank BX-104 Core Composite Analyses Results.

\begin{tabular}{|c|c|c|c|c|c|c|c|}
\hline Sample $=10$ & \multicolumn{2}{|c|}{ Core 1 Composite } & core +2 & dspostate & \multicolumn{2}{|c|}{$\begin{array}{l}\text { Result Total } \\
\text { and stang } \\
\text { Devalution (SD) }\end{array}$} & $\begin{array}{l}\text { Corem } \\
\text { Lquid } \\
\text { Comp }\end{array}$ \\
\hline \multicolumn{8}{|c|}{ 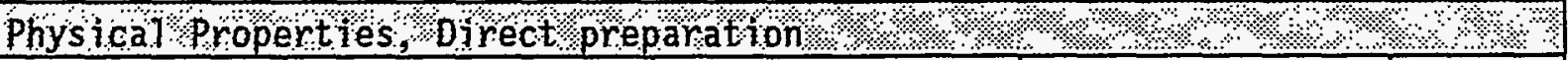 } \\
\hline Appearance & \multicolumn{2}{|l|}{ Brown } & \multicolumn{2}{|c|}{$\begin{array}{l}\text { Brown with small } \\
\text { hard chunks }\end{array}$} & \multicolumn{2}{|c|}{$N / A$} & $\begin{array}{l}\text { Gr } \\
\text { Yellow }\end{array}$ \\
\hline $\begin{array}{l}\text { BuTk Density } \\
(\mathrm{g} / \mathrm{m} \mathrm{l})\end{array}$ & \multicolumn{2}{|c|}{1.85} & \multicolumn{2}{|c|}{1.76} & 1.81 & 0.06 & 1.31 \\
\hline $\mathrm{pH}$ & \multicolumn{2}{|c|}{11.0} & \multicolumn{2}{|c|}{11.0} & 11.0 & 0 & $>12.0$ \\
\hline $\begin{array}{l}\text { Therm wt loss } \\
\text { Amb. to } 400^{\circ} \mathrm{C} C \\
400 \text { to } 1000^{\circ} \mathrm{C}\end{array}$ & \multicolumn{2}{|c|}{$\begin{array}{l}41.9 \% \\
6.4 \%\end{array}$} & \multicolumn{2}{|c|}{$\begin{array}{l}45.6 \% \\
5.8 \%\end{array}$} & $\begin{array}{l}43.8 \% \\
6.1 \%\end{array}$ & $\begin{array}{l}2.6 \% \\
0.4 \%\end{array}$ & $\begin{array}{l}65.2 \% \\
17.3 \%\end{array}$ \\
\hline $\begin{array}{l}\text { Radiation } \\
\mathrm{mR} / \mathrm{h}\end{array}$ & \multicolumn{2}{|c|}{250} & \multicolumn{2}{|c|}{250} & 250 & 0 & 100 \\
\hline \multicolumn{8}{|c|}{ 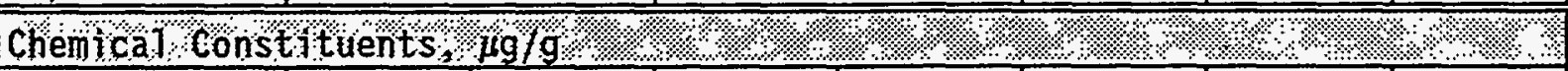 } \\
\hline Result & Water & Acid/fus & Hater & Acid/fus & Tot. Avg & SD & Direct \\
\hline luminum & 1,140 & 39,600 & 1,250 & 52,800 & 47,400 & 9,330 & 3,430 \\
\hline Barium & 0.634 & 1,200 & 1.33 & 2,090 & 1,650 & 620 & $<0.420$ \\
\hline Bismuth & $<11.5$ & 1,690 & $<11.5$ & 1,090 & 1,390 & 420 & $<9.24$ \\
\hline Boron & 5.71 & 93,400 & 5.65 & $0^{b}$ & 93,600 & $N / A$ & 11.3 \\
\hline Cadmium & $<2.6$ & $<21.7$ & $<2.6$ & $<22.4$ & $<25.0^{\circ}$ & $N / A$ & 5.74 \\
\hline Calcium & 44.3 & 3,840 & 75.8 & 5,730 & 4,840 & 1,360 & 110 \\
\hline Chromium & 763 & 2,330 & 421 & 4,060 & 3,790 & 980 & 1,450 \\
\hline
\end{tabular}


HHC-SD-WM-TP-296, REV 0

Table 1. Tank BX-104 Core Composite Analyses Results.

\begin{tabular}{|c|c|c|c|c|c|c|c|}
\hline Samp te ${ }^{1}$ & Core 1 & $\begin{array}{l}\text { omposte } \\
\text { jos }\end{array}$ & $\begin{array}{l}\text { Core } 206 \\
\text { Sol } \\
4\end{array}$ & $\begin{array}{l}\text { Composite } \\
\text { ids }\end{array}$ & $\begin{array}{l}\text { Result T } \\
\text { and } \mathrm{St} \\
\text { Deviat }\end{array}$ & $\begin{array}{l}\text { A. Avg } \\
\text { idard } \\
\text { (SD) }\end{array}$ & $\begin{array}{l}\text { Core +2 } \\
\text { Bquitd } \\
\text { comp. }\end{array}$ \\
\hline Result & Water & Acid/fus & Water & Acid/fus & Tot. Avg & SD & Direct \\
\hline Cobalt & $0^{b}$ & 15.1 & $0^{6}$ & 8.4 & 11.8 & 4.7 & 0.857 \\
\hline Copper & 14.5 & 105 & 1.5 & 70.2 & 95.4 & 33.4 & 43.7 \\
\hline Iron & 1.07 & 9,620 & 1.3 & 5,060 & 7,340 & 3,220 & 2.08 \\
\hline Lead & $<8.5$ & 542 & $<12.4$ & 582 & 562 & 28 & 13.6 \\
\hline Magnesium & 0.356 & 1,900 & 1.7 & 3,040 & 2,470 & 570 & 0.134 \\
\hline Manganese & $<20.9$ & 810 & $<20.9$ & 1,110 & 960 & 150 & $<16.8$ \\
\hline Nickel & 14.2 & 181 & 19.4 & 95.7 & 155 & 57 & 47.6 \\
\hline Phosphorus & 3,890 & 611 & 2,500 & 510 & 3,760 & 1,050 & 1,350 \\
\hline Potassium & 492 & 464 & 511 & 644 & 1,060 & 140 & 1,510 \\
\hline Silicon & 135 & 25,700 & 127 & 38,800 & 32,400 & 9,200 & 119 \\
\hline Silver & $<1.1$ & 107 & $<1.1$ & 69.8 & 88 & 26 & $<0.840$ \\
\hline Sodium & 53,900 & 15,900 & 44,600 & 22,900 & 68,700 & 1,600 & 124,500 \\
\hline Strontium & $0^{6}$ & 77.1 & 0.112 & 46.5 & 61.9 & 21.6 & 0.160 \\
\hline Zinc & $0^{b}$ & 121 & $0^{6}$ & 102 & 112 & 13 & NR \\
\hline Zirconium & $<4.8$ & 1,130 & $<4.8$ & 1,360 & 1,250 & 160 & $<3.87$ \\
\hline Uranium & 3.80 & 34,800 & 2.83 & 14,000 & 24,400 & 14,700 & 2.56 \\
\hline Nitrate & 41,900 & NR & 35,000 & NR & 38,500 & 4,900 & 111,000 \\
\hline TOC & 1,780 & NR & 2,710 & NR & 2,250 & 660 & 4,721 \\
\hline \multicolumn{5}{|c|}{ Radionuclide Constituents, $\mu \mathrm{C} / \mathrm{q}$} & ৪: : & \multicolumn{2}{|c|}{ \% } \\
\hline $239,240 \mathrm{Pu}$ & $2.12 \mathrm{E}-3$ & 0.339 & $1.33 \mathrm{E}-3$ & 0.389 & 0.366 & 0.035 & $1.37 \mathrm{E}-2$ \\
\hline $14 \mathrm{C}$ & $6.28 E-4$ & NR & $<3.5 E-4$ & NR & $6.28 E-4$ & N/A & $1.23 E-3$ \\
\hline $90 S r$ & 0.197 & 375 & 0.362 & 15.4 & 265 & 156 & 2.07 \\
\hline 99Tc & $3.35 \mathrm{E}-2$ & $0^{b}$ & $3.23 E-2$ & $0^{6}$ & $3.29 E-2$ & $0.08 \mathrm{E}-2$ & $9.32 \mathrm{E}-2$ \\
\hline 241Am & $<2.05 \mathrm{E}-3$ & $<0.225$ & $5.75 \mathrm{E}-3$ & 1.03 & 1.03 & $N / A$ & $<6.2 E-3$ \\
\hline $60 \mathrm{Co}$ & $1.50 \mathrm{E}-2$ & $6.20 \mathrm{E}-2$ & $2.84 \mathrm{E}-2$ & $<3.17 \mathrm{E}-2$ & $7.70 \mathrm{E}-2$ & $N / A$ & $<7.6 \mathrm{E}-2$ \\
\hline $137 \mathrm{Cs}$ & 59.2 & 15.9 & 64.3 & 59.5 & 99.6 & 35.6 & 168 \\
\hline $129 \mathrm{I}$ & \multicolumn{2}{|c|}{$5.20 \mathrm{E}-5$, direct } & \multicolumn{2}{|c|}{$<3.50 \mathrm{E}-5$, direct } & $5.20 E-5$ & $N / A$ & $8.40 \mathrm{E}-5$ \\
\hline Total Gamma & 60.7 & 25.4 & 66.4 & 80.1 & 117 & 43 & 171 \\
\hline
\end{tabular}

$\mathrm{NR}=$ Not reported $\quad \mathrm{N} / \mathrm{A}=$ Not Applicable

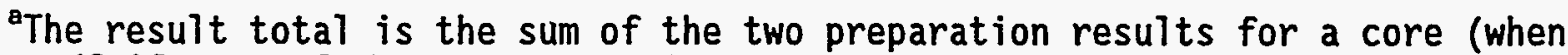
available), excluding results below the detection limit. The core \#1 and Core \#2 result totals are then averaged.

Beported as zero with no detection limit indicated.

${ }^{{ }^{N}}$ ot an average but a maximum value. 
In June of 1990, vapor samples were collected when unpleasant "fuel oil type" odors were reported emitting from tanks BX-104 and B-110. A 5-L vapor sample was drawn from each of tanks BX-104, B-110, and five other BX Farm tanks' breather exhaust ports through charcoal tubes. NIOSH Reference Methods $1003,1500,1501$, and 1550 utilizing GC/FID were used to detect benzene and total hydrocarbons at the HHC Environmental Health Sciences laboratory. Benzene was not detected at levels above the $0.2 \mathrm{ppm}$ method detection 7 imit in any sample. Residual hydrocarbon concentrations of $\leq 500 \mu \mathrm{g} / \mathrm{m}^{3}$ were reported for a11 BX Farm tanks except BX-104, which was $210,000 \mu \mathrm{g} / \mathrm{m}^{3}$. The major organic components in the $B X-104$ sample were identified as $C_{10}-C_{22}$ paraffins using CG/MS. Ammonia and acetone detector tube samples from tank $B X-104$ indicated the presence of ammonia and an absence of acetone (Wegener 1990).

In contradiction to these results, the Oregon Graduate Institue of Science and Technology analyzed vapor samples, collected in canisters on January 19, 1993, from tank BX-104. Both T0-12 and T0-14 EPA procedures were used on six tank samples, one trip blank, and one field blank. All TNMHC levels were below $10,000 \mu \mathrm{g} / \mathrm{m}^{3}$, the majority of which was identified as smallchain paraffins $\left(\leq \mathrm{C}_{6}\right)$. These samples were used to collect screening data and is not qualified data. Table 2 gives results for both the 1990 and 1993 (Rasmussen 1993) tank BX-104 samples. The representativeness of the samples is in question since neither sampling event used the current Type 2 or Type 3 sample collection procedures.

\subsection{Expected Tank Contents}

An in-tank photograph montage from September 1989 is incomplete and hazy but shows the waste surface to be a pock-marked glossy black sludge with smal1 pools of liquid at the bases of the turbine pump and FIC gauge. The photographs were taken about the same time the tank was jet pumped and interim stabilized and may not represent the tank's current contents (Brevick et at. 1994).

Approximately 83,000 L of supernatant have been removed since the 1986 core sampling event. Therefore, the analytical results of the solids composites presented in Table 1 should be representative of the present contents of the tank after consideration of radionuclide decay, chemical reactivity, and remaining interstitial liquid. The tank is expected to contain a large amount of insoluble aluminum and other metal silicates, uranium oxide, and soluble nitrates and phosphates. The majority of the organic liquid, expected to be present as a floating layer, was obtained from the middle portion of the 1986 cores. Therefore, this organic fluid may be a contaminate originating from core sampling equipment or the tank may contain pockets of interstitial organic liquid.

Organic vapors, detected as odors in the air near tank BX-104 by field workers and at $210,000 \mu \mathrm{g} / \mathrm{m}^{3}$ in the tank's exhaust port from a charcoal tube sampler in the spring of 1990 , provide evidence that organic material is present within tank BX-104. The waste in tank BX-104 had been disturbed by a jet pump only a few months before these odors were detected and may have exposed organic liquids to waste surface. Increasing ambient surface and seasonal internal tank temperatures would then cause an increase in waste surface volatilty. A much lower concentration of organic vapors was measured in the winter of 1993. 
WHC-SD-WM-TP-296, REV 0

Table 2. Tank BX-104 Vapor Sample Analyses Results.

\begin{tabular}{|c|c|c|c|}
\hline $\begin{array}{l}\text { organics, hig/m } \\
\text { noted otherwise }\end{array}$ & 1990 vapor Sample & $\begin{array}{l}4993 \text { vapor } \\
\text { Resuit Avg }\end{array}$ & $\begin{array}{l}\text { Samples } \\
\text { Standard } \\
\text { Deviation }\end{array}$ \\
\hline $\begin{array}{l}\text { NIOSH residual } \\
\text { hydrocarbons (GC/FID) }\end{array}$ & 210,000 & NR & NR \\
\hline TNMHC by T0-12 & NR & 8,900 & 440 \\
\hline TNMHC by T0-14 & NR & 6,810 & 190 \\
\hline Benzene & $\leq 0.2 \mathrm{ppm}$ & 5.3 & 0.5 \\
\hline Ammonia & Detected & NR & \\
\hline Acetone & Not Detected & NR & \\
\hline Ethane & NR & 770 & 19 \\
\hline Ethylene & $\mathrm{NR}$ & 1,041 & 26 \\
\hline Propane & NR & 998 & 22 \\
\hline Propene & NR & 236 & 10 \\
\hline$i$-Butane & NR & 115 & 3 \\
\hline i-Butene & $\mathrm{NR}$ & 191 & 7 \\
\hline 1, 3-Butadiene & NR & 8.5 & 0.5 \\
\hline n-Butane & NR & 929 & 20 \\
\hline i-Pentane & NR & 174 & 13 \\
\hline n-Pentane & NR & 471 & 16 \\
\hline 2-Methylpentane & NR & 181 & 7 \\
\hline$n$-Hexane & NR & 166 & 7 \\
\hline Toluene & NR & 11 & 2 \\
\hline Al kanes (Paraffins) & NR & 4,000 & 80 \\
\hline Alkenes (01efins) & $\mathrm{NR}$ & 1,450 & 630 \\
\hline Aromatics & NR & 16.7 & 2.0 \\
\hline $\begin{array}{l}\text { Total Identified } \\
\text { Hydrocarbons }\end{array}$ & NR & 5,720 & 120 \\
\hline $\begin{array}{l}\text { Total Unidentified } \\
\text { Hydrocarbons }\end{array}$ & NR & 1,090 & 250 \\
\hline
\end{tabular}

$N R=$ Not reported 


\subsection{REFERENCES}

Babad, H., S. M. Blacker, K. S. Redus, 1994, Data Quality Objective to Support Resolution of the Organic Fue7 Rich Tank Safety Issue, WHC-SD-WM-DQ0-006, Rev. 0, Westinghouse Hanford Company, Richland, Washington.

Brevick, C. H., L. A. Gaddis, E. D. Johnson, 1994, Supporting Document for the Historical Tank Content Estimate: BX-Tank Farm, WHC-SD-WM-ER-311, Rev. 0 , Hestinghouse Hanford Company, Richland, Washington.

Haller, C. S., 1994, Fiscal Year 1995 Tank Waste Remediation System Tank Waste Analysis Plan, WHC-SD-WM-PLN-091, Rev. 0, Westinghouse Hanford Company, Richland, Washington.

Hanlon, B. M., 1994, Tank Farm Surveillance and Waste Status Summary Report for July 1994, WHC-EP-0182-75, Westinghouse Hanford Company, Richland, Washington.

Price D. N., 1994, Rotary Core Vapor Sampling Data Quality Objective, WHC-SDWM-SP-003, Rev. 0, Hestinghouse Hanford Company, Richland, Washington.

Osborne, J. H., J. L. Huckaby, E. R. Hewitt, C. M. Anderson, D. D. Mahlum, B. A. Pulsipher, J. Y. Young, 1994, Data Quality Objectives for Generic InTank Health and Safety Vapor Issue Resolution, WHC-SD-WM-DQ0-002, Rev. 0, Westinghouse Hanford Company, Richland, Washington.

Rasmussen, R. A., 1993, (FAX cover sheet and data tables to Mike Story, March 19), Oregon Graduate Institute of Science \& Technology, Beaverton, Oregon.

Redus, K. S., and H. Babad, 1994, Tank Safety Screening Data Quality Objective WHC-SD-WM-SP-004, Westinghouse Hanford Company, Richland, Washington.

Wegener, D. L., 1990, HEHF Evaluation of Vapor Space in B/BX Tank Farms, (internal memo 86123-90-DLW-204 to distribution 7ist, September 4), Westinghouse Hanford Company, Richland, Washington.

Heiss, R. L., and K. E. Schu1l, 1988, Data Transmittal Package for 241-BX-104 Waste Tank Characterization, SD-RE-TI-206, Rev. 0, Rockweil Hanford Operation, Richland, Washington. 
WHC-SD-WM-TP-296, REV 0

\section{APPENDICES}

\section{TANK 241-BX-104 SAMPLING AND ANALYSIS PLAN}


WHC-SD-WM-TP-296, APPENDIX A, REV 0

SAMPLE EVENT A

\section{VAPOR SAMPLING IN FISCAL YEAR 1995}

A. 0 
WHC-SD-WH-TP-296, APPENDIX A, REV 0

SAMPLE EVENT A: VAPOR SAMPLING IN FISCAL YEAR 1995

TABLE OF CONTENTS

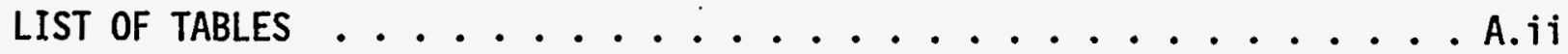

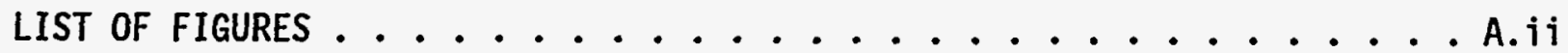

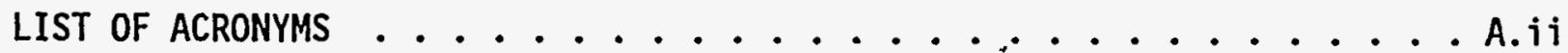

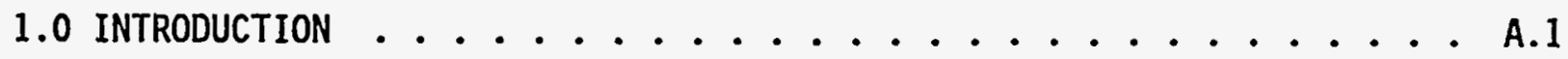

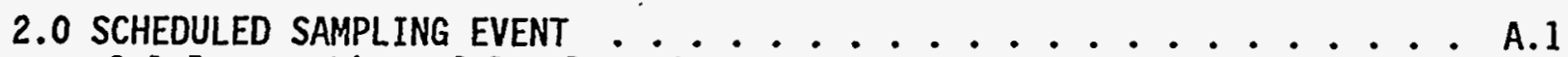

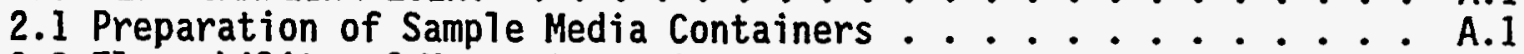

2.2 Flammability of Vapor Space Gases ............ A.1

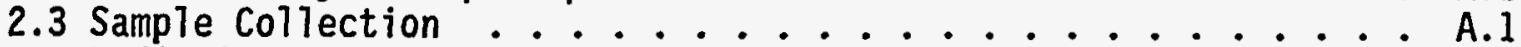

2.4 Radiation Screening and Sample Transport .......... A.2

2.5 Tank-Specific Analytical Procedures ......... A.4

2.5.1 Sampling, Isolation, and Analysis Scheme ....... A.4

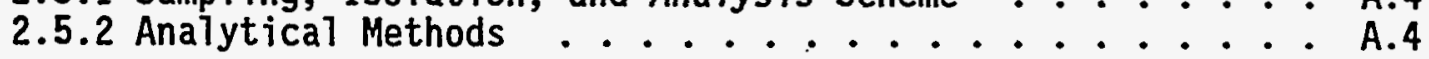

3.0 QUALITY ASSURANCE/QUALITY CONTROL . . . . . . . . . A.7

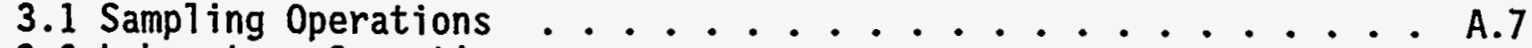

3.2 Laboratory Operations . . . . . . . . . . A.8

4.0 ORGANIZATION . . . . . . . . . . . . . A.9

5.0 EXCEPTIONS, CLARIFICATIONS, AND ASSUMPTIONS .........A.9

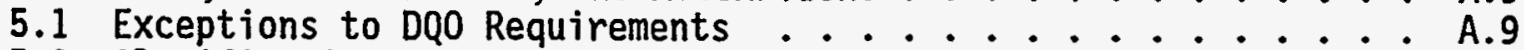

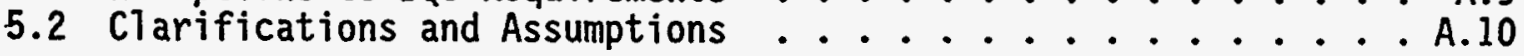

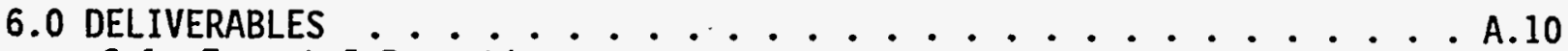

6.1 Format I Reporting . . . . . . . . . . . A.10

6.2 Format II Reporting . . . . . . . . . . . . A.11

6.3 Format VI Reporting . . . . . . . . . . . . A.11

7.0 CHANGE CONTROL . . . . . . . . . . . . . . . . . . . .

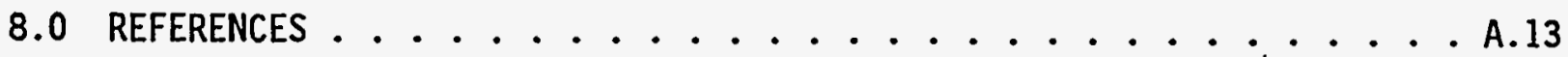




\section{LIST OF TABLES}

Table A.1. General Sampling Information . . . . . . . . . A.2

Table A.2. List of Samples and Activities. . . . . . . . . . . . A.3

Table A.3. Limits For Acceptable Radionuclide Activity Levels. . . . . . A.4

Table A.4. BX-104 Sample Chemical, Physical, and Radiological Analytical

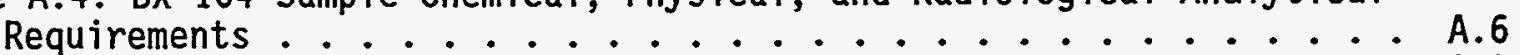

Table A.5. Tank BX-104 Project Key Personnel List. . . . . . . . . . A.9

\section{LIST OF FIGURES}

Figure A.1. Test Plan Outline and Flowchart for Tank Vapor Space Characterization. ..... A.5

\section{LIST OF ACRONYMS}

$\begin{array}{ll}\text { BX-104 } & \text { Tank 241-BX-104 } \\ \text { CERCLA } & \text { Comprehensive Environmental Response, Compensation, and Liability } \\ & \text { Act of } 1980 \\ \text { CGM } & \text { combustible gas meter } \\ \text { DOT } & \text { Department of Transportation } \\ \text { DQO } & \text { data quality objective } \\ \text { EPA } & \text { Environmental Protection Agency } \\ \text { ESH\&QA } & \text { Environmental Safety, Health, and Quality Assurance } \\ \text { FAS } & \text { Field Analytical Services } \\ \text { GC/MS } & \text { gas chromatography/mass spectrometry } \\ \text { HEPA } & \text { high efficiency particulate air } \\ \text { IC } & \text { ion chromatography } \\ \text { IDLH } & \text { immediately dangerous to life and health } \\ \text { LFL } & \text { lower flammability limit } \\ \text { OGIST } & \text { Oregon Graduate Institute of Science and Technology } \\ \text { ORNL } & \text { Oak Ridge National Laboratory } \\ \text { PNL } & \text { Pacific Northwest Laboratory } \\ \text { PpbV } & \text { parts per billion by volume } \\ \text { ppmV } & \text { parts per million by volume } \\ \text { RCRA } & \text { Resource Conservation and Recovery Act } \\ \text { SML } & \text { Sampling and Mobile Laboratories } \\ \text { SUMMA } & \text { registered trademark for passivated stainless steel canister } \\ \text { TCP } & \text { Tank Characterization Plan } \\ \text { TNMHC } & \text { Total Non-Methane Hydrocarbons } \\ \text { TO-14 } & \text { EPA task order protocol 14 } \\ \text { TOC } & \text { total organic carbon } \\ \text { TWRS } & \text { Tank Waste Remediation System } \\ \text { VSS } & \text { vapor sampling system } \\ \text { WHC } & \text { Westinghouse Hanford Company } \\ & \end{array}$


WHC-SD-WM-TP-296, APPENDIX A, REV 0

TANK 241-BX-104 VAPOR SPACE SAMPLING AND ANALYSIS PLAN

\subsection{INTRODUCTION}

Vapor samples are used to identify potential flammable and fugitive vapor emissions from the tanks which could become worker health and safety issues. Sampling of the vapor space can identify: 1) volatile compounds above the surface of the waste; and 2) the amount of gases generated by chemical or radiolytic reactions within the waste.

\section{0 - SCHEDULED SAMPLING EVENT}

The following information provides the methodology and procedures to be used in the preparation, retrieval, transport, analysis, and reporting of results for vapor space samples retrieved from tank $B X-104$. The requirements for sample event $A$, contained within this appendix of the TCP, are within the scope of work specified in the appropriate laboratory financial plans. Any decisions, observations, or deviations to this TCP made during sample receipt, preparation, and analysis shall be documented and justified in the deliverable report.

\subsection{Preparation of Sample Media Containers}

The laboratories performing the contracted analytical work shall supply prepared and labeled sample containers (SUMMA ${ }^{\otimes}$ canisters and/or selective sorbent sampling media) to Field Analytical Services (FAS) at least 48 hours in advance of the scheduled sampling date. Each sample media container sha11 be certified as clean and prepared according to procedures called out in Table A.1. FAS shall provide sample identification numbers to the laboratories following the quality assurance/quality control format given in Section 3.1.

\subsection{Flammability of Vapor Space Gases}

Prior to this sampling event and performing any intrusive work on a tank, an assessment of the flammability of the tank vapor space gases is required by standard WHC safety practices. The flammability test is identified in the sampling event work package and performed by Industrial Hygiene Field Services personnel using a combustible gas meter (CGM). Under present guidelines no operational or sampling activity is permitted if a single sample of the tank vapor fuel content is greater than $20 \%$ of the lower flammability limit (LFL). If the CGM sample measures a total fuel content between $10 \%$ and $20 \%$ of the LFL, a vapor sampling activity may continue under CGM monitoring to better jdentify the hazard level. Under 10\% of the LFL the tank is not considered a flammability problem and all scheduled work can proceed (Osborne et al. 1994).

\subsection{Sample Collection}

In fiscal year 1995, the tank BX-104 vapor space shall be sampled through a heated probe in an available riser using the vapor sampling system (VSS) in accordance with laboratory operating procedure L0-080-450 "Collection of SUMMA@ Canisters \& Sorbent Tube Samples Using the Vapor Sampling System (VSS)". The riser selected for access to the tank vapor space is identified 
in work package ES-94-904. Table A.1 specifies the sample type, the type of collection media to be used, and the number of samples requested. Table A.2 provides a sequence of sampling activities and specifies the sample collection time and the flow rate through the sample collection tubes.

A cleanliness check shall be performed in accordance with procedure L0-080-450, Appendix C. Cleanliness of the VSS shall also be addressed by collecting ambient air SUMMA ${ }^{\circledR}$ samples prior to sampling the tanks using the following conditions: 1) with the VSS manifold and transfer lines fully heated; and 2) without the VSS, upwind of BX-104.

The GC/FID shall be used to monitor organic vapors during the sampling event. The GC/FID shall be operated in accordance with L0-080-450, Appendix D and Bellus (1993).

Table A.1. General Sampling Information

\begin{tabular}{|c|c|c|c|c|}
\hline Sample Container & Prepared By & $\begin{array}{l}\text { Preparation } \\
\text { Procedure }\end{array}$ & Sample Type & $\begin{array}{l}\text { Number of } \\
\text { Samples }\end{array}$ \\
\hline SUMMA ${ }^{\circledR}$ & PNL & PNL-TVP-02 & Tank Air & 6 \\
\hline SUMMA® & PNL & PNL-TVP-02 & $\begin{array}{l}\text { Ambient } \\
\text { Air }\end{array}$ & 2 \\
\hline \multirow[t]{3}{*}{ Triple Sorbent Traps } & ORNL & $\begin{array}{c}\text { AC-0P-300-0907 } \\
\text { CASD-AM-300-WPO1 } \\
\end{array}$ & Tank Air & 12 \\
\hline & ORNL & $A C-0 P-300-0907$ & Field Blank & 2 \\
\hline & ORNL & $A C-0 P-300-0907$ & Trip Blank & 2 \\
\hline \multirow{2}{*}{$\begin{array}{l}\text { Sorbent Trap System } \\
\text { for } \mathrm{NH}_{3}, \mathrm{NO}_{2}, \mathrm{NO}, \mathrm{H}_{2} \mathrm{O}\end{array}$} & PNL & PNL-TVP-09 & Tank Air & 6 \\
\hline & PNL & PNL-TVP-09 & Trip Blank & 3 \\
\hline Tritium Trap & WHC & LA-548-111 & Tank Air & 1 \\
\hline HEPA Filters & WHC & $N / A$ & Tank Air & 4 \\
\hline
\end{tabular}

${ }_{2}^{1}$ One sample taken through the VSS, one sample taken upwind of the tank.

2 preparation procedure for samples spiked with surrogate(s).

\subsection{Radiation Screening and Sample Transport}

A11 vapor samples shall be stored at the 222-S Laboratory Annex while performing a radiological survey of certain items used during sampling. Surveys are conducted to assure compliance with Department of Transportation (DOT) shipping regulations and offsite laboratory acceptance criteria. Items surveyed include four HEPA filters and one tritium trap and shall be analyzed following procedures specified in a Letter of Instruction (Bratzel 1994). These procedures are reproduced in Table A.4.

The results from the radiation screening are submitted to and shall be evaluated by Sampling and Mobile Laboratories to ensure the samples meet the criteria specified in Table A.3. Sampling and Mobile Laboratories shall provide a report to each analytical laboratory to identify the number of picocuries per sample ( $\mathrm{pCi} / \mathrm{sample)}$ for each sample that is submitted for anatysis. 
Table A.2. List of Samples and Activities.

\begin{tabular}{|c|c|c|c|c|}
\hline $\begin{array}{l}\text { SAMPLE } \\
\text { COOE }\end{array}$ & SAMPLE/ACTIVITY DESCRIPTION & $\begin{array}{l}\text { SAMPLER POSITION } \\
\text { DURING COLLECTIOH }\end{array}$ & GAS FLOW RATE & $\begin{array}{c}\text { SAMPLE } \\
\text { DURATION }\end{array}$ \\
\hline-- & Adjust vSS temperature setpoint to $60^{\circ} \mathrm{C}$ & N/A & N/A & H/A \\
\hline$\cdots$ & Purge VSS with ambient air & H/A & $5,450 \mathrm{~mL} / \mathrm{min}$ & $30 \mathrm{~min}$. \\
\hline 01 & Collect ambient air sample sUMMA \#1 & Upwind of $\mathrm{BX}-104$ & $N / A$ & $1 \mathrm{~min}$. \\
\hline$=$ & Perform cleanl iness check & $\mathrm{H} / \mathrm{A}$ & N/A & N/A \\
\hline 02 & Collect ambient air sample SUMMA \#2 & Port 15 & N/A & 1 min. \\
\hline 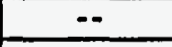 & Leak test & N/A & N/A & N/A \\
\hline-- & Purge VSS with tank air & $\mathrm{H} / \mathrm{A}$ & $5,450 \mathrm{~mL} / \mathrm{min}$ & 30 min. \\
\hline$\because$ & Heasure tank pressure & N/A & H/A & N/A \\
\hline 03 & Collect Tritium Trap & Sorbent line 8 & $200 \mathrm{~m} / \mathrm{min}$ & 5 min. \\
\hline$\cdots$ & Collect GC sample and initiate GC run ${ }^{4}$ & H/A & H/A & $H / A$ \\
\hline 04. & Collect SUMMA \#3 & Port 11 & H/A & 1 min. \\
\hline 05 & Collect SUMMA \#4 & Port 13 & H/A & $1 \mathrm{~min}$. \\
\hline 06 & Collect SUMMA \#5 & Port 15 & N/A & $1 \mathrm{~min}$. \\
\hline 07 & Collect SUMMA \#6 & Port 12 & $\mathbf{H} / \mathbf{A}$ & 1 min. \\
\hline 08 & Collect SUMMA \#7 & Port 14 & H/A & 1 min. \\
\hline 09 & Collect SUMAIA \#8 & Port 16 & N/A & $1 \mathrm{~min}$. \\
\hline 10 & Collect Triple Sorbent Trap (TST) sample \#1 & Sorbent line 9 & $50 \mathrm{~mL} / \mathrm{min}$ & $4 \min$. \\
\hline 11 & Collect TST sample \#2 & Sorbent line 10 & $50 \mathrm{~mL} / \mathrm{min}$ & $4 \mathrm{~min}$. \\
\hline 12 & Collect TST sample \#3 & Sorbent line 8 & $50 \mathrm{~mL} / \mathrm{min}$ & 4 min. \\
\hline 13 & Open, close, \& store TST Field Blank \#1 & In vss truck & $0 \mathrm{~mL} / \mathrm{min}$ & \\
\hline 14 & Collect TST sample \#4 & Sorbent line 10 & $50 \mathrm{~mL} / \mathrm{min}$ & $4 \mathrm{~min}$. \\
\hline 15 & Collect TST sample \#5 & Sorbent line 9 & $200 \mathrm{~mL} / \mathrm{min}$ & 5 min. \\
\hline 16 & Collect TST sample \#6 & Sorbent line 10 & $200 \mathrm{~mL} / \mathrm{min}$ & 5 min. \\
\hline 17 & Collect TST sample $\# 7$ & Sorbent line 8 & $200 \mathrm{~mL} / \mathrm{min}$ & $5 \mathrm{~min}$. \\
\hline 18 & Collect TST sample \#8 & Sorbent line 10 & $200 \mathrm{~mL} / \mathrm{min}$ & $5 \min$. \\
\hline 19 & Collect TST sample \#9 & Sorbent line 9 & $200 \mathrm{~mL} / \mathrm{min}$ & 20 min. \\
\hline 20 & Open, close, \& store TST Field Blank \#2 & In vSS truck & $0 \mathrm{~mL} / \mathrm{min}$ & H/A \\
\hline 21 & Collect TST sample \#10 & Sorbent line 10 & $200 \mathrm{~mL} / \mathrm{min}$ & 20 min. \\
\hline 22 & Collect TST sample \#11 & Sorbent line 8 & $200 \mathrm{~mL} / \mathrm{min}$ & 20 min. \\
\hline 23 & Collect TST sample \#12 & Sorbent line 10 & $200 \mathrm{~mL} / \mathrm{min}$ & 20 min. \\
\hline 24,25 & Store TST Trip Blanks \#1 \& \#2 & None & None & None \\
\hline 26 & Collect $\mathrm{NH3} / \mathrm{NOX} / \mathrm{H} 2 \mathrm{O}$ Sorbent Trap \#1 & Sorbent line 9 & $200 \mathrm{~mL} / \mathrm{min}$ & 15 min. \\
\hline 27 & Collect HH3/NOX/H2O Sorbent Trap \#2 & Sorbent line 10 & $200 \mathrm{~mL} / \mathrm{min}$ & 15 min. \\
\hline 28 & Collect NH3/HOX/H2O Sorbent Trap \#3 & Sorbent line 8 & $200 \mathrm{~m} / \mathrm{min}$ & $15 \mathrm{~min}$. \\
\hline 29 & Collect NH3/HOX/H2O Sorbent Trap \#4 & Sorbent line 10 & $200 \mathrm{~mL} / \mathrm{min}$ & $15 \mathrm{~min}$. \\
\hline 30 & Collect $\mathrm{NH} 3 / \mathrm{HOX} / \mathrm{H} 2 \mathrm{O}$ Sorbent Trap $\$ 5$ & Sorbent line 9 & $200 \mathrm{~m} / \mathrm{min}$ & $15 \mathrm{~min}$. \\
\hline 31 & Collect $\mathrm{HH} 3 / \mathrm{HOX} / \mathrm{H} 2 \mathrm{O}$ Sorbent Trap \#6 & Sorbent line 10 & $200 \mathrm{~mL} / \mathrm{min}$ & $15 \mathrm{~min}$. \\
\hline $32,33,34$ & $\begin{array}{l}\text { Store NH3/HOx/H2O Trap Trip Blanks \#1, } \\
\# 2 \text {, \& \#3 }\end{array}$ & None & None & None \\
\hline 35 & $\begin{array}{l}\text { Remove upstream HEPA Filter from HEPA } \\
\text { transfer box }\end{array}$ & Upstream of box & \multicolumn{2}{|c|}{ Continuous } \\
\hline 36 & $\begin{array}{l}\text { Remove downstream HEPA Filter from HEPA } \\
\text { transfer box }\end{array}$ & Downstream of box & \multicolumn{2}{|c|}{ Cont inuous } \\
\hline 37 & Renove upstream HEPA Filter from VSS & Upstream of vss & \multicolumn{2}{|c|}{ Continuous } \\
\hline 38 & Remove downstrean HEPA Filter from vSS & Downstream of vSS & \multicolumn{2}{|c|}{ Continuous } \\
\hline
\end{tabular}

3 Hot required if ambient air purge incorporated in vSS setup.

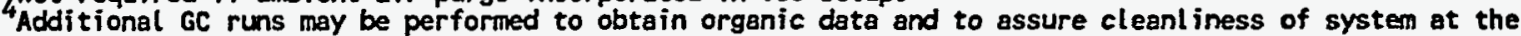
discretion of the sampling scientist and sha!l be identified in the deliverable report. Organic data obtained from the on-line GC is developmental. 
WHC-SD-WH-TP-296, APPENDIX A, REV 0

Table A.3. Limits For Acceptable Radionuclide Activity Levels.

\begin{tabular}{||c|c|c|c|c||}
\hline \multicolumn{1}{|c|}{ Organization } & Total $\alpha$ & Total B/V & Tritium & Units \\
\hline $\begin{array}{l}\text { PNL Analytical } \\
\text { Chemistry Laboratory }\end{array}$ & $\leq 100$ & $\leq 400$ & $\begin{array}{c}\text { none } \\
\text { specified }\end{array}$ & $\mathrm{pCi} / \mathrm{g}$ \\
\hline $\begin{array}{l}\text { Oak Ridge National } \\
\text { Laboratory }\end{array}$ & $\leq 135$ & $\leq 450$ & $\begin{array}{c}\text { none } \\
\text { specified }\end{array}$ & $\mathrm{pCi} / \mathrm{g}$ \\
\hline WHC-CM-2-14 & $\leq 60$ & $\leq 200$ & $\begin{array}{c}\text { none } \\
\text { specified }\end{array}$ & $\mathrm{pCi} / \mathrm{g}$ \\
\hline
\end{tabular}

${ }^{4}$ Samples above these limits may be shipped as Limited Quantity of Radioactive Matorial.

Trip blanks and field blanks are to accompany the waste samples to the laboratory. For specific information concerning sample and blank handling, custody, and transport refer to quality assurance/quality control requirements in Section 3.1.

\subsection{Tank-Specific Analytical Procedures}

A flowchart and narrative showing the sample collection, isolation, and analysis scheme is presented as Figure A.1. All samples are to be prepared and analyzed in accordance with this scheme. Sample receipt, custody, preparation, and analysis shall be performed in accordance with approved procedures.

Sample material retrieved from the tank BX-104 vapor space and contained within the SUMMA ${ }^{\circledR}$ canisters shall be analyzed for total non-methane hydrocarbons following modified EPA procedure T0-14 and the permanent gases $\mathrm{CO}_{2}, \mathrm{CO}, \mathrm{CH}_{4}, \mathrm{H}_{2}$, and $\mathrm{N}_{2} \mathrm{O}$ using gas chromatography. The sorbent traps contain analyte-specific sorbent media and shall be analyzed for these specific analytes. The triple sorbent traps contain sorbent media designed to allow a broad range of organic species to be retained. Table A.4 identifies the appropriate laboratory procedures used in each analysis.

Any analyses prescribed by this document, but not performed, shall be identified and justification for non-performance written in the appropriate data report. If there are insufficient samples to perform all requested analyses, a partial listing of the analyses in Table A.4 that could be performed with available samples will be developed by Tank Vapor Issue Resolution Program personnel. The Taboratory shall proceed with these analyses. 
-Step 1 Labs: Prepare sample and blank containers at contract laboratories. Label containers using sample identification numbers and sampling data provided by Field Analytical Services.

-Step 2 Labs: Ship containers to Field Analytical Services at least 48 hours in advance of scheduled sampling event. Receipt and control of containers shall be guided by procedures PNL-TVP-07 and CASD-AM-300-WPO2 (ORHL).

-Step 3 SHL: If tank is safe with regard to flammability, set up vapor sampling system (VSS) and collect samples following procedure 10-080-450 and guidel ines in Table A.2.

-Step 4 SML: Move to the 222-S Laboratory, the vapor sample SML: Move to the 222-s Laboratory, the HePor filters and containers for locked storage, and the

-Step 5 SHL: Using radiological survey report results, determine if samples are acceptable to ship offsite (see Section 2.4).

-Step 6 SML: If determined to be acceptable by offsite laboratory requirements and $\mathrm{HHC}-\mathrm{CM}-2-14$, ship samples and blanks following Dor requirements. If not acceptable to ship. maintain samples in storage and contact $J$. H. Osborne of Vapor Issue Resolution Program for further direction.

-Step 7 Labs: Perform Laboratory analyses.

A. SUMma Canisters (PNL): Perform modified full scan EPA-TO-14. Perform permanent gas analysis for the following: $\mathrm{H}_{2}, \mathrm{CO}, \mathrm{H}_{2} \mathrm{O}, \mathrm{CH}_{4}, \mathrm{CO}_{2}$.

B. Sorbent Traps (PNL): Perform gravimetric analys is for moisture. Perform selective electrode analys is for $\mathrm{NH}_{3}$ Analyze $\mathrm{NO}$ and $\mathrm{NO}_{2}$ Traps.

C. Triple Sorbent Traps (ORNL): Perform organic vapor analysis.

-Step 8 Labs and SML: Following the Section 6.0 reporting

requirements, deliver a Format VI Report to the Vapor Issue Resolution Safety Program.

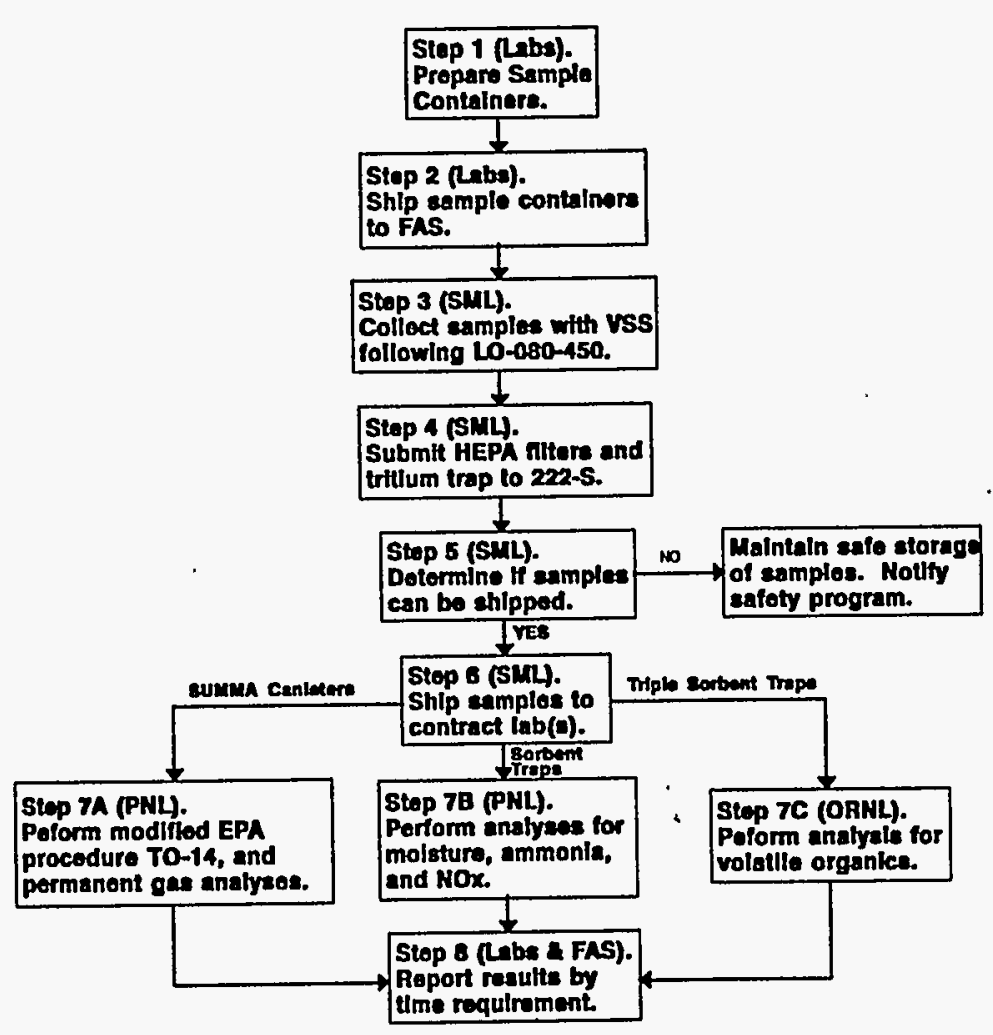


WHC-SD-WM-TP-296, APPENDIX A, REV 0

Table A.4. BX-104 Sample Chemical, Physical, and Radiological Analytical Requirements

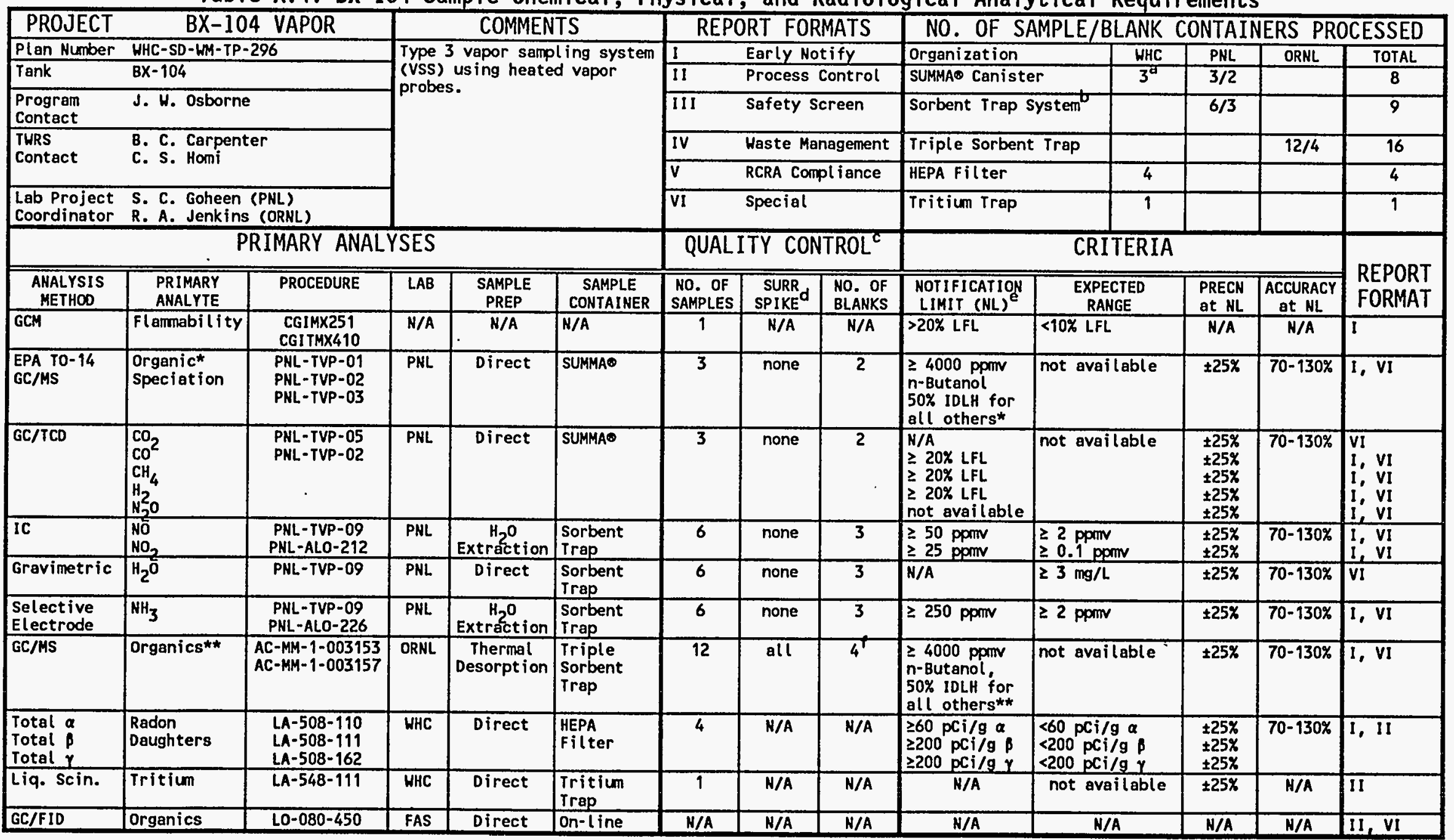

H/A: Not Applicable

Three canisters will be archived at PNL until arrangements can be made for transport and analytical work at the OGIST laboratory.

b System contains individual sorbent media sections for $\mathrm{NO}_{x}, \mathrm{NH}_{3}, \& \mathrm{H}_{2} \mathrm{O}$.

c Mustem contains individual sorbent media

c Multiple samples and blanks are

e Action required if any compound exceed $50 \%$ IDLH.

$f$ Includes two trip and two field blanks.
*Acetone, acetonitrile, benzene, 1,3-butadiene, butanal, n-butanol, orer species detected at levels deemed sufficient by the laboratory scientist to be of potential toxicological concern shall be reported following format I.

**Acetone, acetonitrile, benzene, butanol, $n$-dodecane, $n$-hexane, propane nitrile, tributyl phosphate, n-tridecane. Other organic species detected at level deemed sufficient by the laboratory scientist to be of potential toxicological concern shall be reported following format 1 . 


\subsection{QUALITY ASSURANCE/QUALITY CONTROL}

This Tank Characterization Plan and analytical laboratory operations are approved by the WHC Environmental Safety, Health, and Quality Assurance (ESH\&QA) Program provided the following conditions are met.

1) Each laboratory has a quality assurance program that meets the applicable requirements of DOE order 5700.6C, American Society of Mechanica7 Engineers NQA-1, EPA QAMS-005/80 or United States 10 CFR 830.120 .

2) Each analysis and media preparation procedure given in Tables $A .1$ and A.4 is documented by the laboratory and available to ESH\&QA.

3) Any modifications made to, or deviations from, the prescribed procedures are documented and justified in the deliverabie report.

The PNL tank vapor program has an impact level II Laboratory Quality Assurance Plan (Barnes 1994) written to comply with 5700.6C. ESH\&QA will qualify laboratories for continued use by the TWRS Characterization program after receipt of the Laboratory quality assurance plans, followed by an audit and corrective action phase.

\subsection{Sampling Operations}

Field Analytical Services shall provide unique sample label and identification numbers to the laboratories supplying the sample collection medium. Each sample identification number shall have the following format:

SXXXX-WYY-LLL, where:

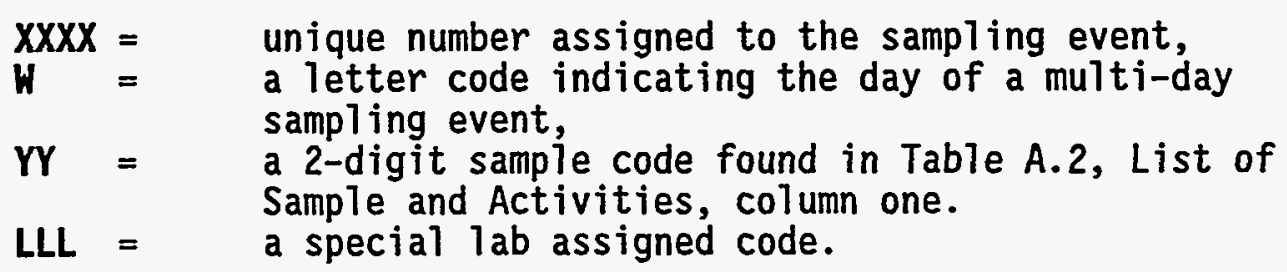

Once the sample collection media has been received by FAS from the laboratory, it shall remain in the physical control of the custodian, locked in a secure area, or prepared for shipping with tamper evident tape. The sample collection media shall also remain in a controlled area under conditions specified on the chain-of-custody form.

Applicable operating procedures for the tank BX-104 vapor space sampling activities are contained in work package ES-94-904. Vapor samples, trip blanks, and field blanks are to be collected in accordance with Tables A.1 and A.2 and Taboratory operating procedure L0-080-450 "Collection of SUMMA Canisters \& Sorbent Tube Samples Using the Vapor Sampling System (VSS)" and shipped to the analytical laboratories in accordance with Hazardous Material Packaging and Shipping, WHC-CM-2-14.

All sampling activities shall be documented in controlled field logbooks maintàined by sampling personnel (Sampling and Mobile Laboratories) and shall contain, but are not limited to: 
1) identification of tank and riser number and photographs of the sample location in which the sampling is conducted,

2) if any anomalies are observed, corresponding sample identification numbers, flow rates, pressures, temperatures, and other operational parameters affecting the sample,

3 ) any conditions that the sampler may observe during the sampling event ( $i$. e., odors, nearby machinery in operation, etc.),

4) names and titles of personnel involved in the field activity and their responsibilities,

5) instrument calibration dates.

Sampling and Mobile Laboratories is responsible for documenting any problems and procedural changes affecting the validity of the sample in a controlled field notebook and shall enter this information in the comment section of the chain-of-custody form for addition to the data reports.

\subsection{Laboratory Operations}

Prepared and labeled sample collection containers, trip blanks, and field blanks are supplied by the performing laboratories to FAS. The SUMMA® canisters and Sorbent Trap Systems are prepared and certified following the laboratory quality control procedures identified in Table A.1. The laboratory supplying the sample collection media shall initiate the chain of custody in accordance with the laboratory operating procedure L0-090-443, "Chain-ofCustody for RCRA and CERCLA Protocol Samples" using sample label and identification numbers provided by Field Analytical Services.

The sample receipt and control steps used by the PNL 1aboratories are identified in procedure PNL-TVP-07. Oak Ridge National Laboratory shipping and receiving is done by procedure CASD-AM-300-WP02. The analytical procedures used are identified in Table A.4.

Method specific quality control such as calibrations and blanks are also found in the analytical procedures. Sample quality control (duplicates, spikes, standards) are identified in Table A.4. If no criteria are provided in Table A.4, the performing laboratory shall analyze quality control samples according to its Quality Assurance Plan $(s)$.

Due to the developmental work being done with the analysis procedures and potential sample differences (between tanks), changes in procedures may be needed. These changes must be documented in controlled notebooks and referenced in the deliverable reports to ensure traceability. 


\subsection{ORGANIZATION}

The organization and responsibility of key personnel involved in this tank BX-104 vapor sampling project are listed in Table A.5.

Table A.5. Tank BX-104 Project Key Personnel List.

\begin{tabular}{|c|c|c|}
\hline Individual (s) & Organization & Responsibility \\
\hline S. C. Goheen & $\begin{array}{c}\text { Pacific Northwest } \\
\text { Laboratory }\end{array}$ & $\begin{array}{l}\text { Project Manager for Vapor } \\
\text { Sample Characterization }\end{array}$ \\
\hline R. A. Jenkins & $\begin{array}{l}\text { Oak Ridge National } \\
\text { Laboratory }\end{array}$ & $\begin{array}{l}\text { Project Manager for Vapor } \\
\text { Sample Characterization }\end{array}$ \\
\hline J. G. Kristofzski & WHC 222-S Laboratory & $\begin{array}{c}\text { Project Manager for Sample } \\
\text { Radiological Survey }\end{array}$ \\
\hline $\begin{array}{l}\text { B. C. Carpenter } \\
\text { C. S. Homi } \\
\end{array}$ & $\begin{array}{c}\text { TWRS Characterization } \\
\text { Support }\end{array}$ & $\begin{array}{c}\text { BX-104 Tank Characterization } \\
\text { Plan Engineers }\end{array}$ \\
\hline J. W. Osborne & $\begin{array}{l}\text { TWRS Tank Vapor Issue } \\
\text { Resolution Program }\end{array}$ & $\begin{array}{c}\text { Vapor Issue Resolution } \\
\text { Program Manager }\end{array}$ \\
\hline H. Babad & $\begin{array}{c}\text { TWRS Characterization } \\
\text { Program }\end{array}$ & $\begin{array}{c}\text { Tank. Safety Screening } \\
\text { Scientist }\end{array}$ \\
\hline R. S. Viswanath & $\begin{array}{c}\text { Field Analytical } \\
\text { Services }\end{array}$ & $\begin{array}{c}\text { Special Analytical Studies } \\
\text { Vapor Sampling Technical } \\
\text { Support } \\
\end{array}$ \\
\hline R. D. Mahon & $\begin{array}{c}\text { Field Analytical } \\
\text { Services }\end{array}$ & $\begin{array}{c}\text { Sampling and Mobile } \\
\text { Laboratories Vapor Sampling } \\
\text { Program Lead }\end{array}$ \\
\hline E. H. Neilsen & $\begin{array}{c}\text { Waste Tank Safety } \\
\text { Engineering }\end{array}$ & $\begin{array}{l}\text { Vapor Sampling } \\
\text { Cognizant Engineer } \\
\end{array}$ \\
\hline D. R. Carls & $\begin{array}{l}\text { Industrial Hygiene } \\
\text { and Safety Program }\end{array}$ & $\begin{array}{l}\text { Industrial Hygiene Point of } \\
\text { Contact if Notification Limit } \\
\text { is Exceeded (FAX 372-3522) }\end{array}$ \\
\hline $\begin{array}{c}\text { East Area Shift } \\
\text { Operations } \\
\text { Manager } \\
\end{array}$ & Tank Farm Operations & $\begin{array}{c}\text { East Tank Farm Point of } \\
\text { Contact if Notification Limit } \\
\text { is Exceeded (373-2689) }\end{array}$ \\
\hline
\end{tabular}

\subsection{EXCEPTIONS, CLARIFICATIONS, AND ASSUMPTIONS}

Trip $B 7$ anks and Field Blanks

Trip Blanks are sampling devices prepared and handled in the same manner as samples, except that they are never opened in the field. Field Blanks are sampling devices prepared and handled in the same manner as the samples, but no tank gases are drawn through them. Laboratories supplying blanks may opt to analyze only 1 trip blank unless it is determined to be contaminated, in which case al1 trip blanks are to be analyzed. 


\section{Sample Custodian}

The sample custodian is the designated FAS cognizant scientist or assisting scientific technician, lead sampler, or laboratory scientist or technician who signs the received by block on the chain-of-custody. Transfer of custodianship occurs when the custodian signs the relinquished by block on the chain-of-custody and releases the sample(s) to the new custodian signator.

\section{Physical Control}

Physical control of a sample includes being in the sight of the custodian, in a room which shall signal an alarm when entered, or locked in a cabinet.

\subsection{DELIVERABLES}

The Pacific Northwest Laboratory, Oak Ridge National Laboratory, and Sampling and Mobile Laboratories VSS sampling and analyses of tank BX-104 vapors shall be reported as Format VI (Section 6.3). In addition, the analytical laboratories shall receive Format II reports from Sampling and Mobile Laboratories as described in Section 6.2. Any analyte exceeding the notification 1 imit prescribed in Table A.4 shall be reported as Format I (Section 6.1). Other organic species detected at levels deemed sufficient by the laboratory scientist to be of potential toxicological concern shall also be reported following Format I. Additional information regarding reporting formats is given in Schreiber (1994a, 1994b, 1994c).

\subsection{Format I Reporting}

Table A.4 contains the notification limits for specific analytes. Analytes that exceed notification limits defined in the DQO processes shall be reported by the Project Manager, delegate, or Health Physics Management by calling the East Area Shift Manager of Tank Farm Operations at (509) 373-2689 immediately. This verbal communication must be followed within 3 working days by written communication to J. W. Osborne of the Tank Vapor Issue Resolution Program, D. R. Carls in the Industrial Hygiene and Safety Program, and D. R. Bratzel of the Characterization Program, documenting the observation(s). A further review of the data, including quality control results and additional analyses for verification of the exceeded analyte, may be contracted between the performing laboratory and the contacts above.

\subsection{Format II Reporting}

Results of the 222-S Laboratory's radiological survey shall be reported by Sampling and Mobile Laboratories as Format II to the vapor analytical laboratories 1 isting the picocuries per sample (pCi/g/sample) for each sample submitted for analysis. This Format II report should also provide the sample collection sequence and volumes, verification of trip and field blank use, and any anomalous sampling conditions to accompany, if possible, the shipment of samples. Alternative1y, this sampling report may be transmitted by FAX to the analytical laboratories within 48 hours after the samples have been shipped. 


\subsection{Format VI Reporting}

All Format VI reports shall be delivered to J. W. Osborne of the Tank Vapor Safety Resolution Program, R. S. Viswaneth of Field Analytical Services, the Characterization Program Office, Analytical Services, and the Tank Characterization Resource Center.

Each analytical laboratory and SML shall deliver three reports.. Sampling and analytical data are requested within 5 weeks after receipt of both the samples and supporting data and shall consist of, at a minimum, data tables reporting sample collection data, industrial hygiene tank monitoring data, and radiation screening results obtained by SML, or the results of each analysis performed by the analytical laboratories. A final report shall be delivered within a nine week period after receipt of both the samples and supporting data. A cleared final report shall be delivered after it has completed the proper clearance. Final reports shall be submitted to clearance in parallel to being submitted to the WHC customers identified above.

The final sampling report from Sampling and Mobile Laboratories shall be a WHC supporting document, with sponsor-7imited release. It should include:

1) A description of sampling equipment used;

2) a description of sampling quality controls applied (e.g., leak and cleanliness tests of the sampling manifold, system temperature and pressure monitoring/alarms, instrument calibration details);

3) sampling event chronology and sample collection schedule (complete list of samples, by ID\#, time collected, flow rates, etc.);

4) any industrial hygiene tank monitoring data collected before or during sampling event;

5) an evaluation of sources of sampling errors;

6) sample radiation screening results;

7) sample storage and shipment details; and

8) copies of ali chain-of-custody forms.

The cleared final report from the analytical laboratories shall be acceptable for distribution to the public. To the extent possible, the final reports should include:

1) A summary of analytical results;

2) a description of sample device preparation (and manufacture if appropriate), citing procedures and logbooks used;

3) references providing traceability of sample device cleanliness;

4) a brief description of analytical methods, with procedures cited;

5) a brief explanation of how analytical systems control was demonstratably maintained;

6) a brief description of sample storage and shipment conditions, citing procedures and logbooks used;

7) a listing of analytes of quantitation (target analytes), with analytical method detection 7 imit, range for which instrumentation is calibrated, number of calibration points used, and statistical data on linearity of calibration; 
8) quantitative analytical results, expressed as dimensionless (ppmv or ppbv) concentration, and mass concentration $\left(\mu \mathrm{g} / \mathrm{m}^{3}, \mathrm{mg} / \mathrm{L}\right.$, etc., calculated at $0{ }^{\circ} \mathrm{C}$ and $1 \mathrm{~atm}$ ) of target analytes (identified by name and Chemical Abstract Service number) in each tank air sample;

9) tentative identification and semi-quantitative analytical results, expressed in both mass and dimensionless concentrations (if possible) of non-target organic analytes (identified by name and Chemical Abstract Service number) in each organic vapor sample;

10) a statistical summary (i.e., mean, standard deviation) for multiple analyses and/or multiple samples for all, analytes (positively and tentatively identified compounds) in both mass and dimensionless concentrations (if possible);

11) a summary of a 11 exceptional conditions, such as deviations from procedure or protocol, results obtained outside of instrument calibration range, sorbent trap breakthrough of analytes, or poor surrogate recoveries; and

12) copies of chain-of-custody forms attached.

\subsection{CHANGE CONTROL}

Under certain circumstances, it may become necessary for the performing laboratory to make decisions concerning a sample without review of the data by the customer or the Characterization Program. These changes shall be brought to the attention of the project manager and the Characterization Program as quickly as possible and documented accordingly. Changes must be justified in their documentation. Changes may be documented through the use of internal change notices or analytical deviation reports for minor, low-impact changes. All significant changes (such as changes in scope) shall be documented by Characterization Support via an Engineering Change Notice to this Tank Characterization Plan. All changes shall also be clearly documented in the final data package.

Additional analysis of sample material from this vapor space characterization project at the request of the Characterization Program shall be performed according to a revision of this Tank Characterization Plan. 


\subsection{REFERENCES}

American Socjety of Mechanical Engineers, NQA-1, Quality Assurance Program Requirements for Nuclear Facilities.

Barnes, B. 0., 1994, Quality Assurance PJan for TWRS Waste Tank Safety Program, MCS-027 Rev. 4, Pacific Northwest Laboratory, Richland, Washington.

Bratzel, D. R., 1994, Letter or Instruction for Radiological Analyses to Support Fiscal Year 1995 Tank Vapor Sampling, (internal memo 74310-94-32 to J. G. Kristofzski, November 30), Hestinghouse Hanford Company, Richland, Washington.

Bellus, T. H., 1993, Configuration of Hewlett Packard (HP) 5890 Series II Gas Chromatograph (GC) for DMLI, (internal memo 12240-SAA93-039 to L. L. Lockrem, JuTy 10), Hestinghouse Hanford Company, Richland, Washington.

Environmental Protection Agency, QAMS-005/80, Interim Guidelines and Specifications for Preparing $Q A$ Project Plans.

Keller, K. K., 1994, Quality Assurance Project P7an for Tank Vapor Characterization, WHC-SD-WM-QAPP-013, Rev.2, Westinghouse Hanford Company, Richland, Washington.

Meznarich, H. K., 1994, Quality Assurance Program Plan for Laboratory Analysis and Process Testing, HHC-SD-CP-QAPP-003, Rev. 1, Westinghouse Hanford Company, Richland, Washington.

Osborne, J. W., J. L. Huckaby, E. R. Hewitt, C. M. Anderson, D. D. Mahlum, B. A. Pulsipher, J. Y. Young, 1994, Data Quality Objectives for Generic InTank Health and Safety Vapor Issue Resolution, WHC-SD-WM-DQO-002, Rev. 0, Westinghouse Hanford Company, Richland, Washington.

Schreiber, R. D., 1994a, Format I Reporting Requirement, (internal memo 7E720-94-128 to J. G. Kristofzski, August 15), Westinghouse Hanford Company, Richland, Washington.

Schreiber, R. D., 1994b, Revised Interim Tank Characterization Plan Guidance, (letter 7E720-94-121 to C. S. Haller, May 13), Westinghouse Hanford Company, Richland, Washington.

Schreiber, R. D., 1994c, Point of Contact/Distribution List, (internal memo 7E720-94-141 to J. G. Kristofzski, October 11), Westinghouse Hanford Company, Richland, Washington.

United States Department of Energy Order 5700.6C, of 08-21-91, Quality Assurance.

United States Code of Federal Regulations, 10 CFR Part 830, Nuclear Safety Management; Section 120, Quality Assurance Requirements.

Whelan, T. E., 1994, TWRS Characterization Program Quality Assurance Program Plan, WHC-SD-WM-QAPP-025, Westinghouse Hanford Company, Rich7and, WA. 